Scientia Marina 76(1)

March 2012, 17-28, Barcelona (Spain)

ISSN: 0214-8358

doi: 10.3989/scimar.2012.76n1017

\title{
Stock boundaries for fisheries assessment and management in the Mediterranean: the Balearic Islands as a case study
}

\author{
ANTONI QUETGLAS, BEATRIZ GUIJARRO, FRANCESC ORDINES \\ and ENRIC MASSUTÍ \\ Instituto Español de Oceanografía, Centre Oceanogràfic de les Balears, Moll de Ponent s/n, 07015 Palma, Spain. \\ E-mail: toni.quetglas@ba.ieo.es
}

\begin{abstract}
SUMMARY: The stock concept plays a pivotal role in fisheries assessment and management. Stocks are defined according to biological, geographical, economic or socio-political factors. The General Fisheries Commission for the Mediterranean (GFCM) has established thirty management geographical sub-areas (GSAs) based on political and statistical considerations rather than biological or economic factors. Here, we present our view on the main biological and ecological aspects that should be considered for delineating different management units in the Mediterranean. We focus on the Balearic Islands (GSA05) as a case study highlighting its specificities compared to the adjacent coast of the Iberian Peninsula (GSA06), but the approach could be generalized to the problem of identifying stock boundaries in other areas. The work is based on published information from different marine disciplines such as geomorphology, ecology and fisheries, combined with the analysis of new data coming from official fishery statistics and scientific surveys. This approach avoids the important drawbacks (inconclusive results, high costs) of other time-consuming techniques used in stock identification, such as genetics. According to the information presented, we conclude that GSA05 should be maintained as an individualized area for assessment and management purposes in the western Mediterranean.
\end{abstract}

Keywords: stock boundary, fishery assessment and management, General Fisheries Commission for the Mediterranean (GFCM), Balearic Islands, Mediterranean Sea.

RESUMEN: DEFINICIÓN DE LÍMITES EN LA EVALUACIÓN Y GESTIÓN DE STOCKS MEDITERRÁNEOS: LAS ISLAS BALEARES COMO CASO DE ESTUDIO. - El concepto de stock juega un papel clave en la evaluación y gestión de pesquerías. Los stocks se definen en base a factores biológicos, geográficos, económicos o socio-políticos. La Comisión General de Pesca para el Mediterráneo (CGPM) ha establecido treinta subáreas geográficas de gestión (GSAs) basándose más en consideraciones políticas y estadísticas que en factores biológicos o económicos. En este trabajo presentamos nuestro punto de vista sobre los principales aspectos que deberían considerarse para definir diferentes unidades de gestión en el Mediterráneo. Aunque nos hemos centrado en las Islas Baleares (GSA05) como caso de estudio, resaltando sus especificidades en relación a las costas adyacentes de la Península Ibérica (GSA06), el enfoque podría generalizarse al problema de la identificación de stocks en otras áreas. El trabajo combina el uso de información publicada de diferentes disciplinas marinas como la geomorfología, ecología y pesquerías, con el análisis de datos inéditos procedentes de estadísticas pesqueras oficiales y campañas científicas. El enfoque que presentamos evita importantes inconvenientes (resultados no concluyentes, elevados costes) de otras técnicas más complejas y laboriosas utilizadas en la identificación de stocks como la genética. En base a la información presentada, concluimos que la GSA05 debería mantenerse como un área individualizada para la evaluación y gestión en el Mediterráneo Occidental.

Palabras clave: límites de stock, evaluación y gestión pesquera, Comisión General de Pesca para el Mediterráneo (CGPM), Islas Baleares, mar Mediterráneo.

\section{INTRODUCTION}

The definition and identification of stocks play a key role in fisheries assessment and management.
Stocks can be defined as intraspecific groups of randomly mating individuals with temporal or spatial integrity (Ihssen et al. 1981, Waldman 2005). Although the terms stock and population are synonyms, the first 
one generally applies to exploited marine species such as fishes and shellfishes (Shaklee and Currens 2003). In practice, it is not easy to identify stocks because the delimitation of adjacent populations involves many difficulties, especially in the sea where there are no clear geographical barriers. Different methods have been used for stock identification such as genetics, morphometry, parasites and others (Cadrin et al. 2005). Most of these techniques, however, are not useful for practical purposes owing to inconclusive results or high costs (Cope and Punt 2009). Therefore, fishery scientists have to adopt compromises to delineate entities for monitoring harvested stocks, such as management units or geographic areas. A variety of partly conflicting factors are used to delineate these entities, such as biological, geographical, economic, social or even political factors (Reiss et al. 2009).

This is the case of the Mediterranean, where the General Fisheries Commission for the Mediterranean (GFCM) has established thirty management areas (Fig. 1) based on political and statistical considerations rather than biological or economic factors (Lleonart and Maynou 2003). A first map of these areas was determined in the ad hoc Working Group on Management Units Definition and Limits held in Alicante (Spain) from 23 to 25 January 2001. This map was based on limits of national jurisdiction, continental shelf geography and documents presented by a number of participants. Furthermore, the waters surrounding islands were considered as independent management units. The report of the fourth session of the Scientific Advisory Committee (SAC) of the GFCM reviewed the conclusions and recommendations of this Working Group, and suggested changing the name of the "management units" to "sub-areas" or "geographical units" because the independent management units could not be taken into consideration due to a lack of information on fleet, stocks and socio-economic parameters. The $26^{\text {th }}$ Session of the GFCM finally agreed that the management units should be referred to in the future as "geographical sub-areas".

The GFCM's objectives are to promote the development, conservation, rational management and best utilization of living marine resources, as well as the sustainable development of aquaculture in the Mediterranean, Black Sea and connecting waters (www.gfcm.org). According to Resolution GFCM/31/2007/2, the thirty geographical sub-areas (GSAs) were established "recalling the efforts made by the Scientific Advisory Committee (SAC) and its Sub-Committees to identify appropriate boundaries for sub-areas in the GFCM area (FAO area 37)" and "recognizing the need to compile data, monitor fisheries and assess fisheries resources in a georeferenced manner". As a result of these efforts, the waters around the Balearic Islands were recognized as an independent sub-area (GSA05), different from the adjacent waters of the Spanish Mediterranean coast (Northern Spain, GSA06). In spite of this, the Report of the 12th Session of the Scientific Advisory Committee (GFCM, 2010a) contains an advisory comment for management of demersal species such as hake in GSA05. This comment suggests the need to improve the knowledge of the stock boundary in this area and to explore the possibility of combining data from GSA05 and GSA06. However, this comment was not supported by clear comprehensive reasoning. On the other hand, the Working Group on Stock Assessment of Demersal Species (GFCM 2010b) identified some situations, e.g. hake stocks, where the definition of stock units may not be well defined and could impact on the stock assessment results. To our knowledge, these are the only concerns on the issue of stock boundaries during recent GFCM meetings.

It is well known that the problem of stock boundaries has generally been controversial for management agents (Reiss et al. 2009), not only in the Mediterranean but also in other areas, such as the northeast Atlantic, which is managed by the International Council for the Exploration of the Sea (ICES). The main drawback is the mismatch between the stock limits established by fishery managers and the distribution limits or certain ecological and biological aspects of these stocks. If a species is distributed across different management units or GSAs, the effects of fishing activities in an area may have notable consequences on the status of this species in neighbouring areas. However, biologically (e.g. genetically) homogeneous populations inhabiting different adjacent areas could be managed independently in each individual area provided there is no clear evidence of ecological (e.g. migration) or human mediated (e.g. fishing exploitation) interactions among areas. In fact, it has been shown that stocks do not have to be completely isolated from one another to show demographic independence (Brown et al. 1987; Berntson and Moran 2009).

Although we are not adverse to a re-evaluation of stock boundaries of GFCM-GSAs, we believe this should be carried out considering the entire set of current sub-areas rather than only individual ones. In case this debate is opened again within the framework of the GFCM, we present in this paper our view concerning the main biological and ecological aspects that should be considered for delineating different management units in the Mediterranean. We focus on the Balearic Islands (GSA05) as a case study, but our approach could be generalized to the problem of identifying stock boundaries for fisheries assessment and management in the Mediterranean. In this work we argue, based on scientific grounds, why we consider that GSA05 should be maintained as an individualized area, independent from the adjacent GSA06, for assessment and management purposes in the Mediterranean. The work combines the use of published information from different marine disciplines such as geomorphology, ecology and fisheries, with the analysis of new data coming from official fishery statistics and scientific surveys. 

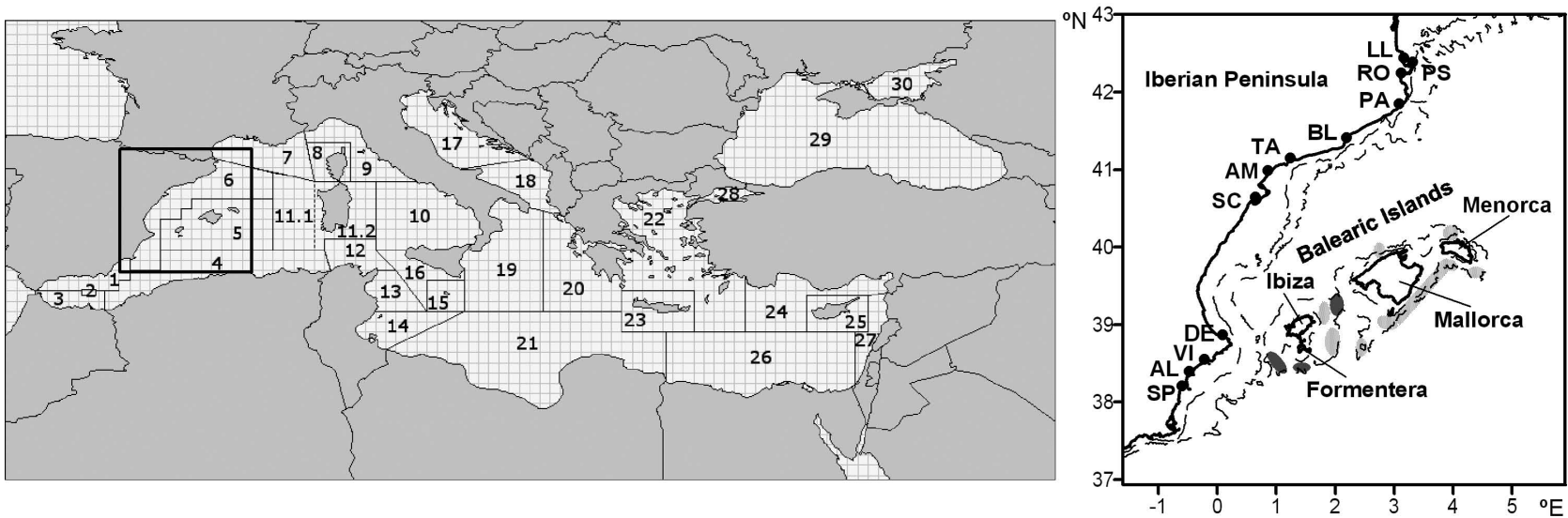

FIG. 1. - Map of the Mediterranean Sea showing the thirty geographical sub-areas (GSAs) established by the General Fisheries Commission for the Mediterranean (GFCM). The inlet details GSA05 (Balearic Islands) and GSA06 (Northern Spain) showing the names of several ports from GSA06 and the different islands of the Balearic Archipelago mentioned in the work; the isobaths are 100 and $800 \mathrm{~m}$. Red shrimp and caridean shrimp fishing grounds of GSA05 exploited by trawlers from GSA06 are also shown in dark grey and grey respectively (adapted from García-Rodríguez and Esteban, 1999; and García-Rodríguez et al. 2000). LL: Llançà; PS: Port de la Selva; RO: Roses; PA: Palamós; BL: Blanes; TA: Tarragona; AM: Ametlla de Mar: SC: Sant Carles de la Ràpita; DE: Denia; VI: Villajoyosa; AL: Alicante; SP: Santa Pola. The number and name of all GFCM-GSAs are: 01 Northern Alboran Sea; 02 Alboran Island; 03 Southern Alboran Sea; 04 Algeria; 05 Balearic Islands; 06 Northern Spain; 07 Gulf of Lions; 08 Corsica Island; 09 Ligurian and North Tyrrhenian Sea; 10 South Tyrrhenian Sea; 11.1 Sardinia (west); 11.2 Sardinia (east); 12 Northern Tunisia; 13 Gulf of Hammamet; 14 Gulf of Gabes; 15 Malta Island; 16 South of Sicily; 17 Northern Adriatic; 18 Southern Adriatic Sea; 19 Western Ionian Sea; 20 Eastern Ionian Sea; 21 Southern Ionian Sea; 22 Aegean Sea; 23 Crete Island; 24 North Levant; 25 Cyprus Island; 6 South Levant; 27 Levant; 28 Marmara Sea; 29 Black Sea; and 30 Azov Sea.

\section{MATERIALS AND METHODS}

To support our view of maintaining GSA05 separated from GSA06 for stock assessment and management purposes, we have analyzed and compared the following characteristics of both areas: 1) geomorphology; 2) type of habitats; 3) fisheries; 4) living resources; and 5) exploitation state of resources and ecosystems. In the first section, the main morphostructural features of the Balearic Islands and the particularities of its geographical location were described and compared with adjacent areas of the western Mediterranean using published information. To develop the remaining sections, we used both published information and the analysis of new data. The main habitats present in the fishing grounds of both areas were described using available literature and data from MEDITS (Mediterranean Trawl Surveys; Bertrand et al. 2002) carried out in GSA05 and GSA06. In relation to habitat characteristics, we also described the existing differences in the relative importance of the two sympatric red mullets (Mullus barbatus and M. surmuletus), which are one of the most important demersal fishing resources in the area.

The main fisheries from both areas were described in terms of number of boats and species composition of the landings using available fishery statistics (catches per day and vessel) from 2000 to 2009. To compare the main marine living resources between GSA05 and GSA06, we analyzed the different fishing tactics (FTs) used by trawlers and their corresponding species compositions in both areas. Mediterranean fisheries are characterized by the spatial and temporal variability of their fishing strategies, which mainly depend on the bathymetric range and determine both the target spe- cies and the demersal communities exploited (e.g. Colloca et al. 2003; Massutí and Reñones 2005). Identifying FTs, which are defined as a combination of target species, gear and fishing location at a given time of the year (Pelletier and Ferraris 2000), is a key point in fisheries that show such heterogeneity of fishing practices. The similarity of the main FTs of each study area was examined by means of cluster analysis (Bray-Curtis coefficient and unweighted pair-group method with arithmetic mean, UPGMA). Mean catches, by boat and day, of the most important commercial species by FT from Mallorca (GSA05) and up to 11 ports of GSA06 were used, after assigning FTs following the methodology described by Palmer et al. (2009). Subsequently, the species composition of each FT from Mallorca and three representative ports of GSA06 (Palamós, Santa Pola and Sant Carles de la Ràpita; Fig. 1) was compared.

In order to compare the exploitation state of the main demersal resources, results from traditional mono-specific assessments of red mullets (M. barbatus and M. surmuletus), European hake (Merluccius merluccius), Norway lobster (Nephrops norvegicus) and red shrimp (Aristeus antennatus) were analyzed. These species were chosen because: 1) they are target species of different FTs used along the entire bathymetric range exploited by the trawl fishery; and 2) they are periodically assessed within the framework of the GFCM or STECF (Scientific, Technical and Economic Committee for Fisheries; https://stecf.jrc.ec.europa.eu/) using the same methodology in both areas (GSA05 and GSA06), and hence the results are fully comparable. Firstly, we analyzed the population structure of all five species using data taken on board commercial trawlers and scientific vessels (MEDITS), testing differences in 
size distributions between GSAs with the KolmogorovSmirnov test. The stock modal size was also compared with the corresponding size at first maturity $\left(\mathrm{L}_{50}\right)$ of each species, which is the size at which $50 \%$ of the population is mature. In all cases, the $\mathrm{L}_{50}$ was obtained with the R package INBIO (Sampedro et al. 2005) using data from the Spanish Data Collection Regulation. Secondly, we compared the outputs of the yield per recruit (YPR) analysis, a standard model used in fisheries assessment and management to determine fishing stock status. Briefly, the YPR model determines the fishing mortality rate which would be expected to produce the maximum yield $\left(\mathrm{YPR}_{\max }\right)$ from the fishery, commonly termed $\mathrm{F}_{\max }$ (Haddon 2001). Thirdly, we compared the current fishing mortality (F) obtained from virtual population analysis (VPA), which is a measure of the loss of fish from a stock caused by fishing exploitation (see Annex 1 for details). Finally, we analyzed the elasmobranch assemblages in both GSAs because this group of fishes are considered ecological indicators owing to the low turnover rate of their populations and high vulnerability to the impact of fishing activities (Stevens et al. 2000, Piet et al. 2009). Total species richness (S), along with mean values of elasmobranch abundance (ind. $\left.\mathrm{km}^{-2}\right)$, biomass $\left(\mathrm{kg} \mathrm{km}^{-2}\right)$, and species richness were analyzed based on data from MEDITS carried out during 2001-2010 in both areas. Mean values were then compared between areas considering the different depth strata studied in these surveys using the Student's t test.

\section{RESULTS}

\section{Geomorphology}

The Balearic Archipelago constitutes (Fig. 1) what is geomorphologically known as the Balearic Promontory, one of the main morphostructural features of the western Mediterranean Basin (Acosta et al. 2002). The Promontory represents a sort of carbonate counterpart to the terrigenous-dominated margins of the Mediterranean Iberian Peninsula. Unlike the mainland, where there is a large amount of terrigenous input from rivers, the Balearic Archipelago does not have any rivers and consequently the sediments of its shelf are mainly biogenic sands and gravels, with a high percentage of carbonates. Furthermore, whereas submarine canyons are scarce on the Balearic margin (only the shelf-break south of Menorca is cut by a canyon head, Canals and Ballesteros 1997), they are abundant in GSA06 where they play an important role in structuring the populations of planktonic communities and benthic megafauna fishery resources, such as hake and red shrimp (Danovaro et al. 2010).

Compared to the nearest mainland, the Balearic Archipelago is one of the most distant insular areas in the Mediterranean. The Promontory and the eastern coast of the Iberian Peninsula are separated by depths of $2000 \mathrm{~m}$, except in the Ibiza Channel (the nearest point between the two coastlines) where the maximum depths are $800 \mathrm{~m}$. Such great depths most probably represent a barrier to the interchange of adult stages of demersal resources exploited by the small-scale and trawl fleets. However, interchanges may occur for pelagic resources, such as those exploited by purse seiners, and pelagic larval stages of different species. Consequently, the split between GSA05 and GSA06 really constitutes a natural impassable barrier. In most cases, however, the political boundaries established among GSAs do not match the natural barriers and there are even cases where adjacent sub-areas share the same continental shelf (e.g. the Strait of Bonifacio separating GSA08 and GSA11.2; and all adjacent GSAs sharing the same coastline).

\section{Habitat types}

The oligotrophy of the waters around the Balearic Archipelago is even more pronounced than that of adjacent waters off the Iberian coast and the Gulf of Lions (Estrada 1996). This and the lack of river inputs due to a dry climate, the reduced watershed areas, and the karstic nature of most of the islands that favours rapid infiltration of rainfall explain the high transparency of the waters in the area and favour the production of benthic biogenic sediments (Canals and Ballesteros 1997). Owing to these physical characteristics, the light intensity can reach $0.05 \%$ of surface values as deep as $110 \mathrm{~m}$, which allows seaweeds to grow on most of the Balearic Islands' continental shelf (Canals and Ballesteros 1997). In this scenario, the red algae beds, whose two main communities are maërl and Peyssonnelia beds, dominate the coastal continental shelf landscape down to depths of $85 \mathrm{~m}$ (Fornós et al. 1988, Ballesteros 1994, Ordines and Massutí 2009), a deeper bathymetric range than that of the Iberian Peninsula and the Gulf of Lions, where these types of bottoms are restricted to depths above $60 \mathrm{~m}$ (Ballesteros 1988, Bordehore et al. 2003). Despite the high biodiversity and productivity of red algae beds (Ordines and Massutí 2009, Ordines et al. 2009) and maërl beds being considered as sensitive habitats (BIOMAERL Team 2003, Ardizzone 2006) as well as their recent protection by the European Union (EU 2006) these communities are subjected to the effects of trawling (the upper limit of legal trawling activities is $50 \mathrm{~m}$ in the Mediterranean) as a consequence of their deep distribution. The trawl landings from the continental shelf represent about half of the total landings of the Balearic Islands trawl fleet (data provided by the fish auction wharf of Mallorca) and trawling on the red algae beds dramatically influences the amount and composition of the discards in GSA05 compared to GSA06. Trawl discards from the shelf constitute up to $55-70 \%$ of the catch and are composed mainly of red algae and echinoderms in GSA05, whereas they only represent $23-48 \%$ and are dominated by fish in GSA06 (Sánchez et al. 2004, Ordines et al. 2006). 

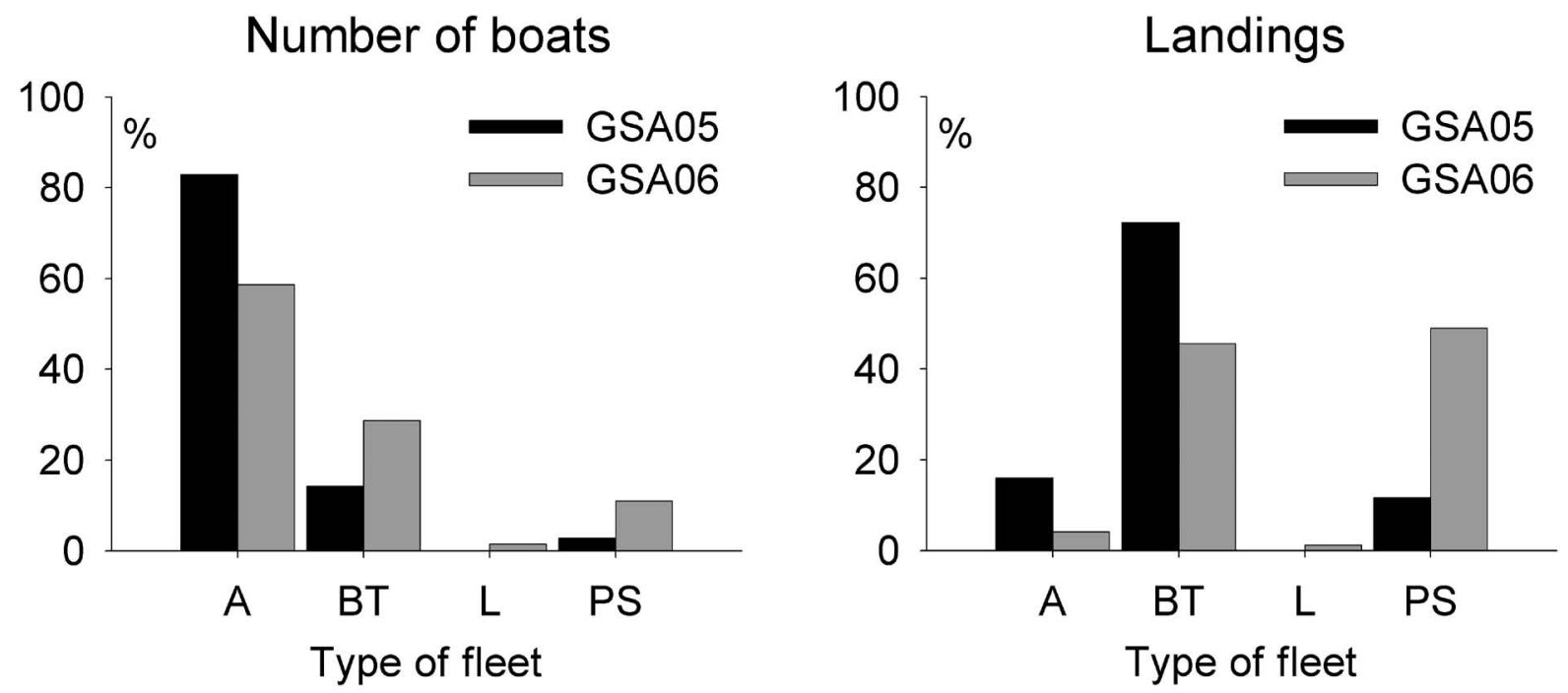

FIG. 2. - Percentage of number of boats (left) and landings in biomass (right) by type of fleet (A: artisanal; BT: bottom trawl; L: long-line; PS: purse-seine) in the geographical sub-areas Balearic Islands (GSA05) and Northern Spain (GSA06).

Along with discards, the relative abundance of some commercially important resources also shows marked differences between GSA05 and GSA06, which are related to the differences in the structure and composition of the fishing grounds. This is the case of the two congeneric, sympatric species of red mullet, Mullus barbatus and M. surmuletus. These species display spatial segregation in relation to habitat throughout the Mediterranean, with M. barbatus and $M$. surmuletus showing a clear preference for soft and rocky bottoms respectively (Lombarte et al. 2000, Tserpes et al. 2002). Accordingly, M. barbatus is a main target species for fishermen working on the soft, muddy grounds of GSA06 continental shelf, but a minor by-catch species in GSA05 where rocky and gravel bottoms predominate on the shelf. The contrary applies to $M$. surmuletus, which is a major target species in GSA05 but a minor by-catch in GSA06. According to MEDITS data (Massutí et al. 2008) on the relative importance of the two species in terms of abundance and biomass, $M$. barbatus represents $37.2 \%$ and $29.7 \%$ respectively in GSA05, but up to $90.8 \%$ and $82.5 \%$ respectively in GSA06.

\section{Fisheries}

Historically, the number of trawl fishing vessels has remained very low in the Balearic Islands compared to other areas of the Mediterranean coast off the Iberian Peninsula. The relative importance of each fishing gear also differs between the two areas. Although the small-scale fleet is the most numerous in both areas, its percentage is much higher in GSA05 $(\sim 80 \%)$ than in GSA06 ( 60\%). However, all other fisheries are larger in terms of number of vessels in GSA06 than in GSA05 (Fig. 2): 1) bottom trawlers represent $30 \%$ in GSA06 but only $15 \%$ in GSA05; 2) purse seiners are scarce in GSA05 (3\%), but represent up to $11 \%$ in GSA06;
3) there are no long-liners in GSA05, but there are some although very few in GSA06. Such differences increase if the proportions of the total landings by fleet are considered (Fig. 2). The bottom trawl fleet is the most important in GSA05, representing more than 70\% of landings, while it does not reach 50\% in GSA06. The most important fleet in GSA06 is the purse seine fleet, whose landings constitute approximately $50 \%$ of the total, while the catches of this fleet only represent around $10 \%$ in GSA05. The landings from the smallscale fishery are four times higher in the Balearic Islands $(16 \%)$ than on the Iberian coast (4\%).

The number of trawlers doubled in Mallorca from 35 to 70 units between 1965 and 1977, but has decreased progressively since then to the 32 current vessels. In the rest of the Balearic Islands, the current number of trawlers is even lower: 7 in Menorca, 8 in Ibiza and 2 in Formentera. These values are clearly very far from the total number of vessels in GSA06, where the fleet has decreased from 810 trawlers in 1998 to the current 567 units (Fernández 2010). There are even individual ports of GSA06 that have more trawlers than all the ports of Mallorca combined, such as Sant Carles de la Ràpita (57), Tarragona (50), Palamós (40) or Castellón (36). As a simple indicator of the fishing effort exerted in different areas of the Spanish Mediterranean coast, Massutí and Guijarro (2004) calculated both the number of trawlers and the gross tonnage (GT) per potential fishing ground surface $\left(\mathrm{km}^{2}\right)$ in the geographic strata of GSA05 and GSA06 considered in the MEDITS program (Table 1). The effort in terms of the number of vessels was one order of magnitude lower in the Balearic Islands than in the other areas.

With the exception of a few vessels of GSA06 working in waters of GSA05 around Ibiza-Formentera (García-Rodríguez and Esteban 1999) and along the eastern slope of Mallorca and Menorca (GarcíaRodríguez et al. 2000), the demersal fleets of the two 
TABLE 1. - Number of trawlers and gross tonnage (GT) per potential fishing ground surface $\left(\mathrm{km}^{2}\right)$ in three GFCM geographical sub-areas (GSAs) from the western Mediterranean Sea: GSA01 (Northern Alboran Sea); GSA05 (Balearic Islands); and GSA06 (Northern Spain). Data is given for the different sectors and strata established within the framework of the MEDITS program. Source: Massutí and Guijarro (2004).

\begin{tabular}{llcc}
\hline GSA & MEDITS sector & Trawlers $\cdot \mathrm{km}^{-2}$ & $\mathrm{GT} \mathrm{km}^{-2}$ \\
\hline 01 & Alboran & 0.015 & 0.57 \\
05 & Mallorca and Menorca & 0.004 & 0.17 \\
06 & Levante & 0.016 & 0.77 \\
06 & Tramontana & 0.032 & 1.40 \\
\hline
\end{tabular}

areas do not interact. In the first case, trawlers, almost exclusively from the ports of Alicante, Denia, Santa Pola and Villajoyosa, carry out trips lasting 4-5 days to mainly fish for red shrimp (Aristeus antennatus) on upper and middle slope bottoms (Fig. 1). The vessels involved in the second fishery, almost exclusively from Santa Pola, use traps to catch the caridean shrimp Plesionika edwardsi on upper slope grounds. These two fleets are regulated by specific management plans regarding fishing trips, because all other vessels are required to return to their homeport daily. Although there are also no interactions between fleets in the case of large pelagic species because this fishery does not exist in GSA05, vessels from GSA06 have traditionally fished in waters around the Balearic Islands.

Unlike the red shrimp, which is one of the most important demersal fisheries in the western Mediterranean, the importance of $P$. edwardsi is limited to some small, local fisheries. Along the whole Spanish Mediterranean coast, for instance, the catches have been reduced to approximately 15 tons per year landed in Santa Pola. The fleet of this port that targets $P$. edwardsi fishes in different GSAs (e.g. Sardinia, Malta; pers. obs.), which implies that the problem of GSA06 vessels reporting landings caught in other areas is not restricted to GSA05. We have estimated from recent fishery statistics (2008-2010) the biomass of red shrimp caught in the Ibiza Channel (GSA05) but landed in GSA06, which accounted for $9.4 \%$ and $22.4 \%$ of the total landings of this species in GSA06 and GSA05 respectively. Although the second percentage could be considered rather high, this fishery only constitutes a local issue that cannot be generalized to the entire GSA06 because: 1) given that the red shrimp fishery can be considered a monospecific fishery, this problem would not significantly affect other commercially important species; 2) the red shrimp fishery in the Ibiza Channel only concerns some vessels of a few ports, all of which are located in the southernmost part of GSA06 between $38^{\circ}$ and $39^{\circ} \mathrm{N}$ (Denia, Villajoyosa, Alicante and Santa Pola); and 3) the catches of these ports only represent $17.3 \%$ of the total landings of GSA06.

\section{Living resources}

The main demersal resources exploited by bottom trawlers throughout GSA05 and GSA06 show important spatial differences, probably related to the differences in the fishing grounds mentioned earlier. These differences are reflected in the fishing tactics (FT) used by trawlers in each area. Trawlers use four different FTs in GSA05 (Palmer et al. 2009), corresponding to the different ecological communities present along the continental shelf and slope (shallow shelf, SS; deep shelf, DS; upper slope, US; and middle slope, MS). However, fishermen usually apply different FTs during the same fishing trip, which gives rise to six additional combinations (SS+DS, SS+US, SS+MS, DS+US, DS+MS, and US+MS) that can be identified in the landings (Palmer et al. 2009). Although all trawlers from all ports of GSA05 use exclusively these FTs, they vary depending on the port in GSA06. To exemplify this, we will describe the FTs applied in three of the most important ports of GSA06 (Palamós, PA; Santa Pola, SP; and Sant Carles de la Ràpita, SC; Fig.
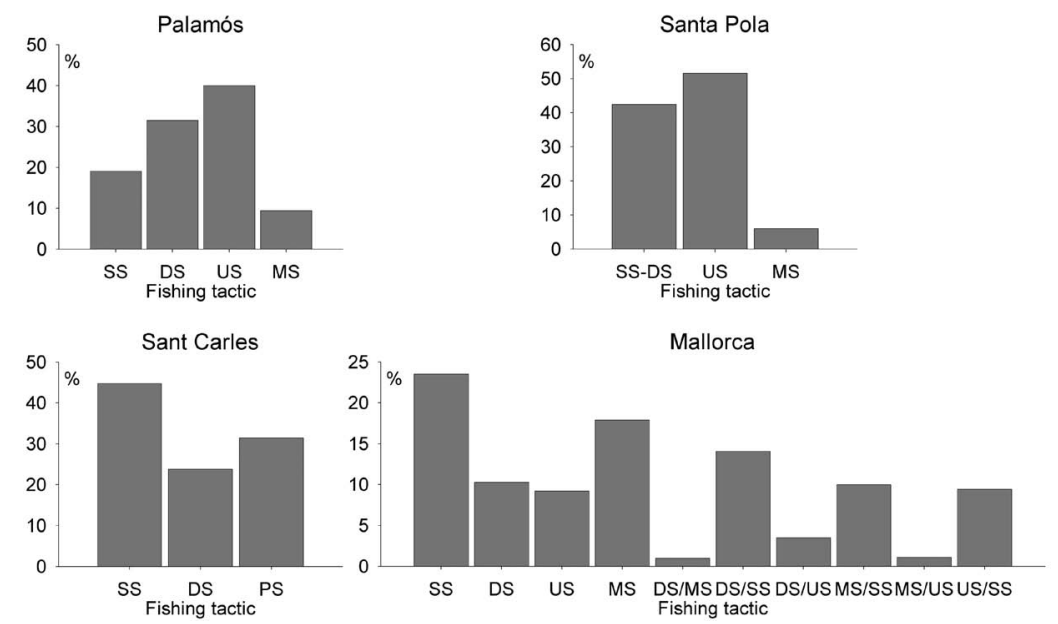

FIG. 3. - Percentage in biomass of total landings for the different fishing tactics obtained analyzing daily landing data from GSA05 (Mallorca) and three important ports of GSA06 (Palamós, Santa Pola and Sant Carles de la Ràpita). SS: shallow shelf; DS: deep shelf; PS: pelagic deep shelf; US: upper slope; MS: middle slope. 


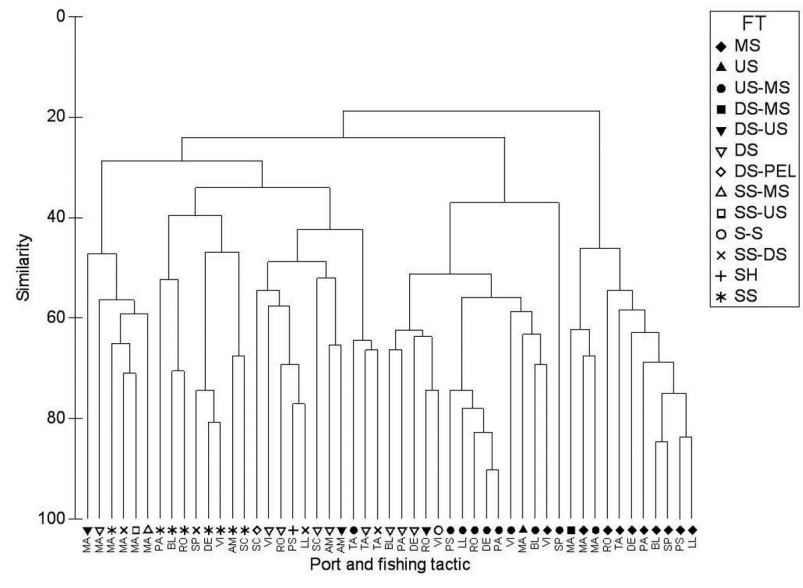

FIG. 4. - Dendrogram of the landings of the most important commercial species by fishing tactic (FT) from different ports of GSA05 (MA: Mallorca) and GSA06 (AM: Ametlla de Mar; BL: Blanes; DE: Denia; PS: Port de la Selva; LL: Llançà; PA: Palamós; RO: Roses; SC: Sant Carles de la Ràpita; SP: Santa Pola; TA: Tarragona; VI: Villajoyosa). SS: shallow shelf; DS: deep shelf; DS-PEL: pelagic deep shelf; US: upper slope; MS: middle slope; S-S: shelf-slope.

1). Trawlers from PA use exclusively the same four individual FTs used in GSA05, although the species composition for these FTs is different (Fig. 3). Vessels from SP and SC only use three different FTs that are different in the two ports: SS+DS, US, and MS in the first case, but SS, DS and DS+PEL in the second one.

The cluster analysis using the landings of the most important species by port and FT of GSA05 and up to 11 ports of GSA06 also revealed notable differences between these two areas (Fig. 4). The FTs corresponding to the faunal assemblages from the continental shelf of GSA05 were clearly separated, at a $25 \%$ similarity level, from the FTs associated with the shallow shelf (SS) and deep shelf (DS) of GSA06. Similarly, the FTs associated with assemblages from the middle slope of GSA05 were separated at about 50\% similarity from those of GSA06.

\section{Exploitation state of resources and ecosystems}

Status indicators for the most important target species of the trawl fishery (red mullets, hake, Norway lobster and red shrimp) using monospecific assessment methods indicate a higher level of overexploitation in GSA06 than in GSA05 (Table 2). First, the current fishing mortality (F) is 1.2-1.7 (red mullets), 2.3 (hake), and 1.8 (Norway lobster and red shrimp) times higher in GSA06 than in GSA05. Second, the maximum YPR is 1.0-1.2 times higher than the current YPR in GSA05, but 1.2-1.8 times higher in GSA06. Considering these differences in the exploitation state of demersal resources between GSA05 and GSA06, merging data from the two areas would result in erroneous assessments of GSA05 stocks because landings of this area are relatively low compared to GSA06 (e.g. red mullet $1.6 \%$, hake $2.4 \%$ ). Owing to such low percentages,
TABLE 2. - Status indicators of fishing exploitation (fishing mortality, F; and yield per recruit, YPR) for the most important demersal target species in two GFCM geographical sub-areas (GSAs) from the western Mediterranean: GSA05 (Balearic Islands) and GSA06 (Northern Spain). For the YPR, the current $\left(\mathrm{YPR}_{\mathrm{curr}}\right)$, maximum $\left(\mathrm{YPR}_{\text {max }}\right)$ and its ratio $\left(\mathrm{YPR}_{\text {ratio }}=\mathrm{YPR}_{\mathrm{max}} / \mathrm{YPR}_{\text {curr }}\right)$ are shown. See Material and Methods and Annex 1 for details. Red mullet: Mullus barbatus; striped red mullet: M. surmuletus; hake: Merluccius merluccius; Norway lobster: Nephrops norvegicus; and red shrimp: Aristeus antennatus.

\begin{tabular}{lccccc}
\hline Species & GSA & $F$ & YPR $_{\text {curr }}$ & YPR $_{\max }$ & YPR $_{\text {ratio }}$ \\
\hline Red mullet & 05 & 0.65 & 11.6 & 12.1 & 1.04 \\
& 06 & 0.77 & 11.7 & 18.7 & 1.60 \\
Striped mullet & 05 & 0.46 & 16.1 & 16.2 & 1.00 \\
Hake & 05 & 0.72 & 22.8 & 28.2 & 1.24 \\
Norway lobster & 06 & 1.69 & 32.8 & 57.7 & 1.76 \\
& 05 & 0.45 & 8.0 & 8.1 & 1.01 \\
Red shrimp & 06 & 1.06 & 10.6 & 13.8 & 1.23 \\
& 05 & 0.63 & 11.1 & 11.5 & 1.04 \\
& 06 & 1.11 & 7.9 & 9.1 & 1.15 \\
\hline
\end{tabular}

joint assessments of these stocks would indicate that resources from GSA05 are in a worse exploitation state than they actually are.

The healthier state of living resources in GSA05 compared to GSA06 is reflected in the population structure of their stocks. The most striking differences occur in hake, whose landings have a well-defined modal size of $20 \mathrm{~cm}$ in GSA05 but $10 \mathrm{~cm}$ in GSA06 (Fig. 5). However, the modal sizes of hake are well below the size of first maturity $\left(\mathrm{L}_{50}=31.9 \mathrm{~cm}\right)$ in both areas. The population structure of red mullet (M. barbatus) in both areas is also very different. Whereas it has a clear mode at $15 \mathrm{~cm}$ and the bulk of the population ranges between 14 and $17 \mathrm{~cm}$ (well above the length at first maturity; $\mathrm{L}_{50}=12.2 \mathrm{~cm}$ ) in GSA05, the population from GSA06 does not have a clear mode and contains many individuals smaller than $\mathrm{L}_{50}$ (Fig. 5). It could be argued in this case that such differences could be because $M$. barbatus is a target species in GSA06 but only a minor by-catch species in GSA05. However, the striped red mullet (M. surmuletus), which is a target species in GSA05, shows similar results in this area (Fig. 5). The bulk of the population is constituted by individuals between 15 and $18 \mathrm{~cm}$, well above the $\mathrm{L}_{50}$ $(14.2 \mathrm{~cm})$. Populations of Norway lobster also differ between zones, and the percentages of individuals below $\mathrm{L}_{50}(25 \mathrm{~mm})$ are about 5\% and 30\% in GSA05 and GSA06 respectively; the modal size is also $10 \mathrm{~mm}$ higher in GSA05 than in GSA06 (35 vs. $25 \mathrm{~mm}$ ). In spite of higher F and $Y_{P R}$ ratio in GSA06 than GSA05, the population structure of red shrimp does not differ between areas in terms of size frequency.

Ecosystem indicators such as the indicator "demersal elasmobranch assemblages" agreed with the results of the monospecific assessment methods. Total species richness was clearly higher in GSA05 $(\mathrm{S}=26)$ than in GSA06 ( $S=19)$. With the only exception of the deepest stratum $(500-800 \mathrm{~m})$, the values of the elasmobranch abundance, biomass and species richness were always significantly higher in GSA05 than in GSA06 (Table 3 ). Differences were highest in the shallowest stratum 
GSA05
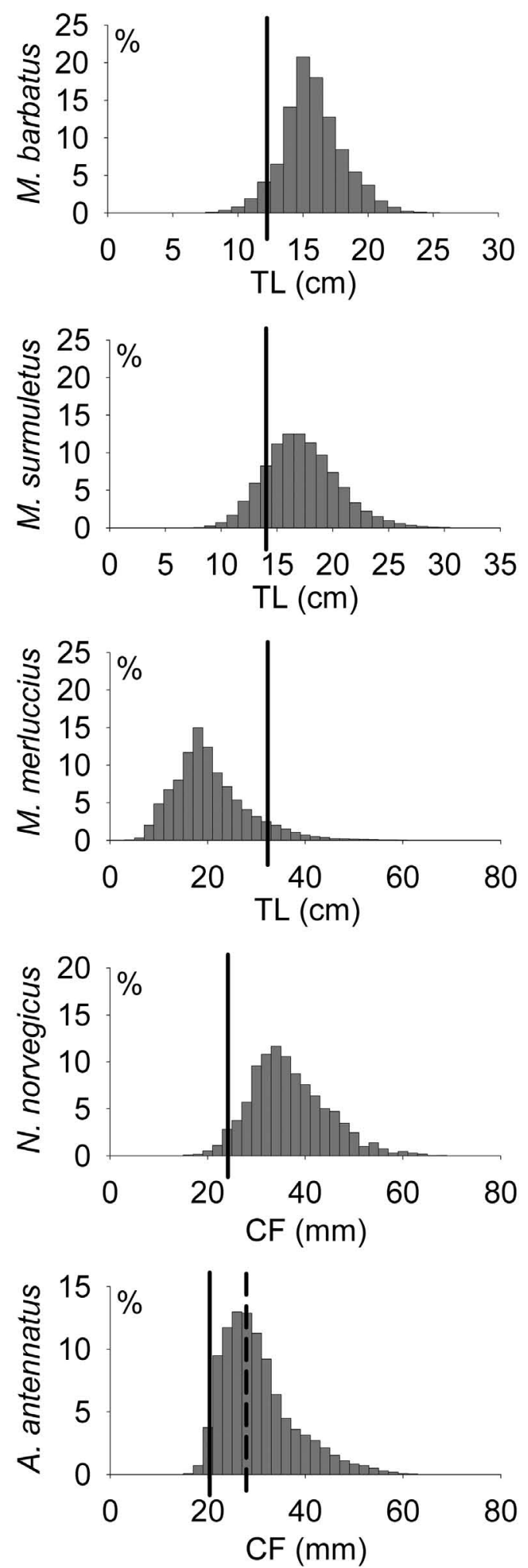

\section{GSA06}

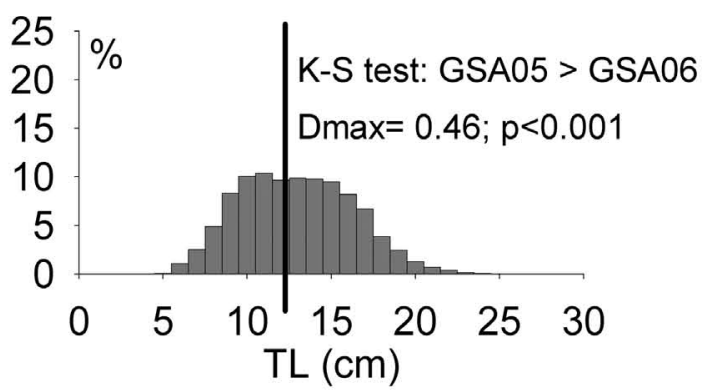

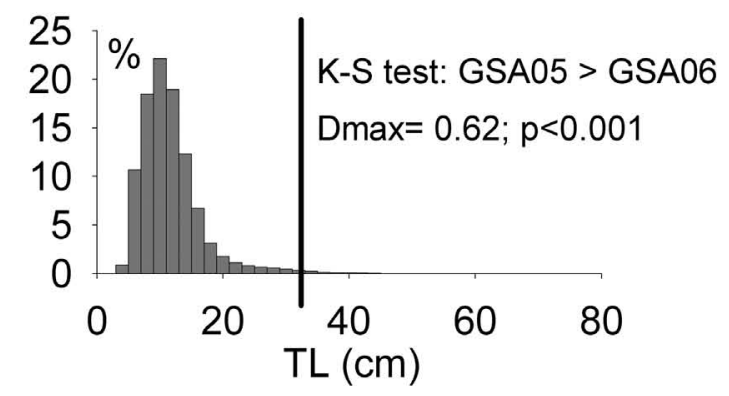
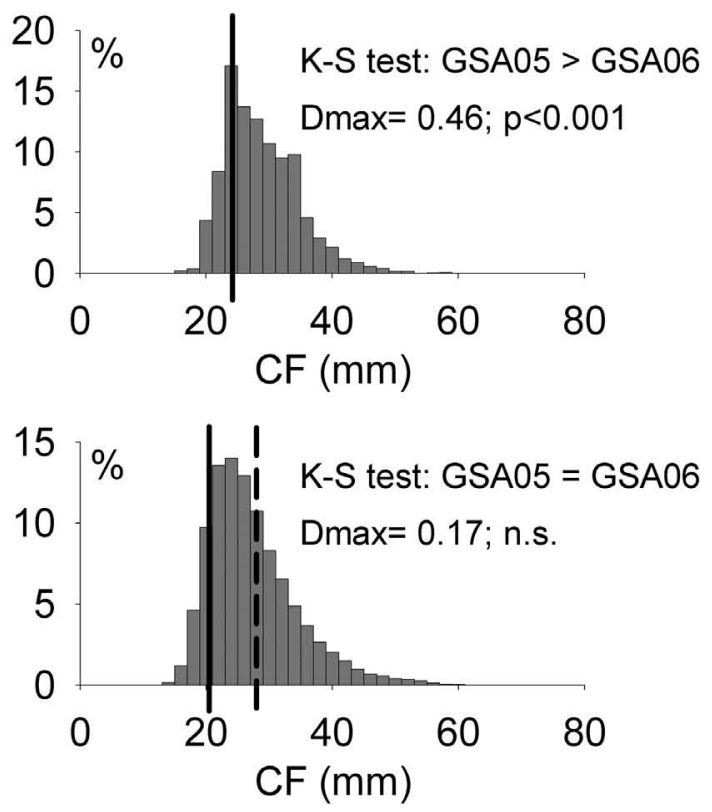

FIG. 5. - Landings size-frequency distributions (TL: total length; CF: cephalothorax length) of the main demersal target species in the geographical sub-areas Balearic Islands (GSA05) and Northern Spain (GSA06). The figure also shows: 1) the results of the Kolmogorov-Smirnov (K-S) test used to compare the distributions of each species between GSAs; and 2) the size at first maturity $\left(\mathrm{L}_{50}\right)$, that is, the size at which $50 \%$ of the population is mature (in the last graph, solid and dotted lines are males and females respectively). Data come from assessments presented to the GFCM and there is no graph of Mullus surmuletus from GSA06 because up to now the species has not been assessed in this area. 
GSA05

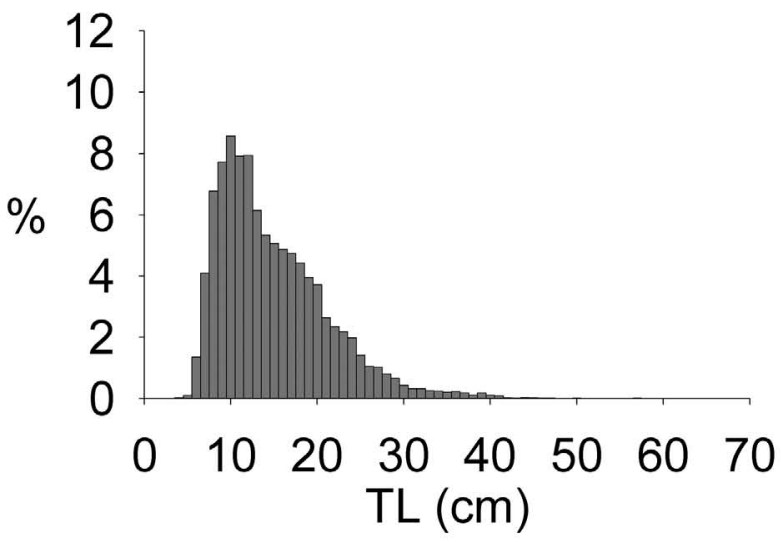

\section{Merluccius merluccius}

GSA06

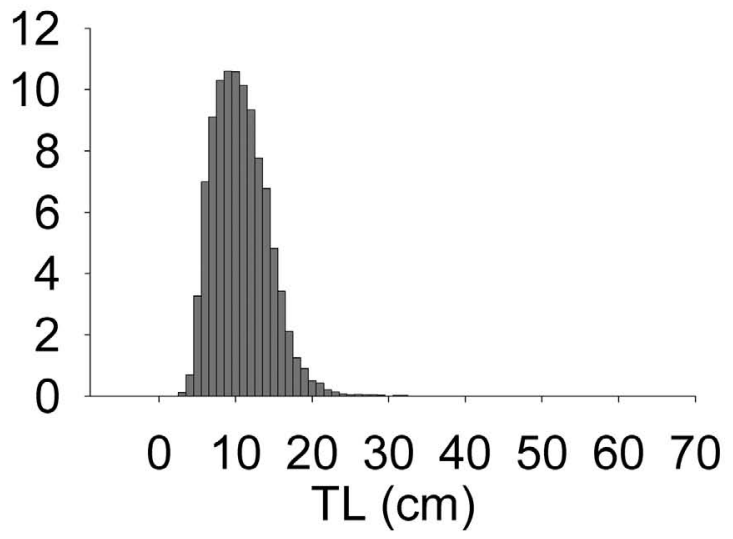

FIG. 6. - Population structure of European hake (Merluccius merluccius) in the geographical sub-areas (GSAs) Balearic Islands (GSA05) and Northern Spain (GSA06) obtained from scientific surveys (MEDITS).

TABLE 3. - Information on elasmobranch assemblages in four different depth strata obtained from MEDITS carried out during 20012010 in the GFCM geographical sub-areas (GSAs) Balearic Islands (GSA05) and Northern Spain (GSA06). Total number of hauls analyzed $(\mathrm{N})$, total species richness (total $\mathrm{S})$, and mean values $( \pm \mathrm{S}$.E.) of abundance (ind. $\left.\mathrm{km}^{-2}\right)$, biomass $\left(\mathrm{kg} \mathrm{km}^{-2}\right)$, and species richness (mean S) per haul are shown. Results of the comparison between areas using the Student's t test are also shown (** significant at $\mathrm{P}<0.001 ;$ n.s. not significant).

\begin{tabular}{|c|c|c|c|c|c|}
\hline Stratum & Index & GSA05 & GSA06 & t-test & d.f. \\
\hline \multirow[t]{5}{*}{$50-100 \mathrm{~m}$} & $\mathrm{~N}$ & 213 & 296 & & \multirow{5}{*}{507} \\
\hline & Total S & 18 & 10 & & \\
\hline & Abundance & $64.2 \pm 4.2$ & $3.5 \pm 0.9$ & $35.3 * *$ & \\
\hline & Biomass & $17.3 \pm 1.2$ & $0.9 \pm 0.2$ & $28.6 * *$ & \\
\hline & Mean S & $3.03 \pm 0.1$ & $0.42 \pm 0.04$ & $29.9 * *$ & \\
\hline \multirow[t]{5}{*}{$100-200 \mathrm{~m}$} & $\mathrm{~N}$ & 162 & 173 & & \multirow{5}{*}{333} \\
\hline & Total S & 18 & 11 & & \\
\hline & Abundance & $74.0 \pm 7.1$ & $19.0 \pm 4.4$ & $14.3 * *$ & \\
\hline & Biomass & $15.1 \pm 4.2$ & $2.7 \pm 0.4$ & $12.8 * *$ & \\
\hline & Mean S & $3.38 \pm 0.1$ & $0.99 \pm 0.06$ & $20.4 * *$ & \\
\hline \multirow[t]{5}{*}{$200-500 \mathrm{~m}$} & $\mathrm{~N}$ & 102 & 137 & & \multirow{5}{*}{237} \\
\hline & Total S & 15 & 10 & & \\
\hline & Abundance & $135.7 \pm 13.2$ & $43.6 \pm 5.7$ & $7.1 * *$ & \\
\hline & Biomass & $8.8 \pm 0.9$ & $4.8 \pm 0.7$ & $4.6 * *$ & \\
\hline & Mean S & $3.26 \pm 0.15$ & $1.54 \pm 0.07$ & $10.6 * *$ & \\
\hline \multirow[t]{5}{*}{$500-800 \mathrm{~m}$} & $\mathrm{~N}$ & 102 & 91 & & \multirow{5}{*}{191} \\
\hline & Total S & 8 & 5 & & \\
\hline & Abundance & $28.6 \pm 8.5$ & $24.3 \pm 3.6$ & -0.44 n.s. & \\
\hline & Biomass & $4.2 \pm 0.7$ & $4.6 \pm 0.6$ & 0.43 n.s. & \\
\hline & Mean S & $2.09 \pm 0.08$ & $2.05 \pm 0.09$ & -0.34 n.s. & \\
\hline
\end{tabular}

(50-100 m), where abundance, biomass and species richness of GSA05 were 18, 19 and 7 times the values of GSA06 respectively. On the 100-200 $\mathrm{m}$ and 200$500 \mathrm{~m}$ depth strata, these values were between 2 and 5 times higher in GSA05 than in GSA06. In fact, the Balearic Islands and other insular areas, where trawling activity is generally low compared to the adjacent mainland waters, show the highest values of diversity and abundance of demersal elasmobranchs in the western Mediterranean (Bertrand et al. 2000, Massutí and Moranta 2003).

\section{DISCUSSION}

Revisiting the stock concept and the best techniques currently available for delineating stocks is out of the scope of this paper; abundant, valuable information dealing with these issues can be found elsewhere (e.g. Begg et al. 1999, Cadrin et al. 2005, Abaunza 2008). Even nowadays an accurate stock definition constitutes a major challenge for fishery scientists, largely because it is still difficult to map directly how far and in what directions larvae disperse (Thresher 1999). In its present form, the stock concept essentially describes characteristics of a population unit assumed to be homogeneous for particular management purposes (Begg and Waldman 1999). Consequently, the stock concept in its current working form defines semi-discrete groups of fish with some definable attributes of interest to managers (Begg et al. 1999). In our opinion, this definition based on practical management purposes would be used by scientists and managers even if genetic studies demonstrated that populations from sub-areas now considered independent constituted genetically homogeneous populations. For example, if a species were found to be genetically homogeneous throughout the Mediterranean, would we assess this population as a whole? We do not believe so, because such an approach would not be useful for practical purposes in this geographic context. We believe that genetic data are only one component of the definition of biological units and the specificities of each area (e.g. geography, marine habitats, fishing practices, socio-economy and policy) should be considered in order to properly assess and manage Mediterranean stocks, particularly if a shift from mono-specific to an ecosystem approach is to be adopted. In the opposite case, if a population complex were to be managed as a single unit, it has been pointed out that the extinction of subpopulations might occur before the analyses of aggregated data indicated a population decline (Frank and Brickman 
2000). Mixing data from sub-areas with marked differences in the state of exploitation of their stocks, such as GSA05 and GSA06, would increase this risk.

In the absence of genetic studies, in the present paper we analyzed the main geological, ecological, and fishery aspects needed to delineate different management units in the framework of the GFCM, taking the Balearic Islands (GSA05) as a case study. As mentioned above, this analysis was carried out in response to suggestions of some GFCM working groups to merge GSA05 with the adjacent GSA06 (Northern Spain). Our view agrees with the holistic approach to defining fish stocks which involves using different complementary techniques, mainly because of the limitations and conditions associated with any particular method (Begg and Waldman 1999, Abaunza et al. 2008). We further consider that stock definition should not be general, but specific on a case-by-case basis (Taylor and Dizon 1999, Begg and Waldman 1999). Keeping all this in mind, we have reported the main specificities of GSA05 which, in our view, are consistent enough to maintain it as an independent unit for assessment and management purposes in the western Mediterranean. Schematically, the main specificities include: 1) Geomorphologically, the Balearic Islands (GSA05) are clearly separated from the Iberian Peninsula (GSA06) by depths between 800 and $2000 \mathrm{~m}$, which would constitute a natural barrier to the interchange of adult stages of demersal resources; 2) Physical geographically-related characteristics, such as the lack of terrigenous inputs from rivers and submarine canyons in GSA05 compared to GSA06, give rise to differences in the structure and composition of the trawling grounds and hence in the benthic assemblages; 3 ) Owing to these physical differences, the faunistic assemblages exploited by trawl fisheries differ between GSA05 and GSA06, resulting in large differences in the relative importance of the main commercial species; 4) There are no important or general interactions between the demersal fishing fleets in the two areas, with only local cases of vessels targeting red shrimp in GSA05 but landing their catches in GSA06; 5) Trawl fishing exploitation in GSA05 is much lower than in GSA06; the density of trawlers around the Balearic Islands is one order of magnitude lower than in adjacent waters; and 6) Due to this lower fishing exploitation, the demersal resources and ecosystems in GSA05 are in a healthier state than in GSA06, which is reflected in the population structure of the main commercial species (populations from the Balearic Islands have larger modal sizes and lower percentages of small-sized individuals), and in the higher abundance and diversity of elasmobranch assemblages. For all these reasons, we conclude that GSA05 should be maintained as an individual area for assessment and management in the western Mediterranean. However, this does not preclude taking into account some local specificities, such as the exploitation of GSA05 fishing grounds by vessels from GSA06. Stock assessments of this red shrimp stock should take into account the biomass taken in
GSA05 but sold in GSA06, reinforcing the idea that stock assessment and management should be specific on a case-by-case basis.

Traditionally, assessment and management agents, such as the International Council for the Exploration of the Sea (ICES) and the GFCM, have delineated stock units by using geo-economic or political aspects related to the collection of fisheries data rather than based on population integrity (Reiss et al. 2009). In the case of ICES, although there is some flexibility in relation to new information, management areas are rarely adjusted to fit the biology of stocks and these adjustments are not based on peer reviewed publications, but on "grey evidence" (Reiss et al. 2009). Here, we have argued, based on peer reviewed scientific grounds and the analysis of new data, why we consider the Balearic Islands should be maintained as an independent GFCM-GSA for stock assessment and management. Our approach, based on geological, ecological and fishery aspects, is in accordance with the implementation of the ecosystem approach to fisheries in the Mediterranean, and avoids the important drawbacks (inconclusive results, high costs) of other time-consuming techniques such as genetics. We hope this work will be useful within the framework of the GFCM in its effort to delineate stocks, and also serve as a starting point for promoting similar analyses from other GSAs.

\section{ACKNOWLEDGEMENTS}

We are grateful to A. Carbonell, M. García-Rodríguez, A.M. Fernández, and J.L. Pérez-Gil (Instituto Español de Oceanografía, IEO) for providing data. Thanks are also given to: 1) all participants in the Spanish MEDITS; 2) the members of the RIM (Red de Información y Muestreo) of the IEO; 3) the fishing sector for their kindness during the samplings on board and at port; 4) the IEO projects MEDER, DEMO, EVADEM, EVADEMED and BADEMECO; and 5) the EU Data Collection Program for co-funding. Special thanks to F. Maynou (ICM-Barcelona) for his useful comments on a first draft of this work.

\section{REFERENCES}

Abaunza P. 2008. Horse mackerel: Identification of stocks: Foreword. Fish. Res. 89: 101-103.

Abaunza P., Murta A.G., Campbell N., Cimmaruta R., Comesana A.S., Dahle G., Santamaria M.T.G., Gordo L.S., Iversen S.A., MacKenzie K., Magoulas A., Mattiucci S., Molloy J., Nascetti G., Pinto A.L., Quinta R., Rarnos P., Sanjuan A., Santos A.T., Stransky C., Zimmermann C. 2008. Stock identity of horse mackerel (Trachurus trachurus) in the Northeast Atlantic and Mediterranean Sea: Integrating the results from different stock identification approaches. Fish. Res. 89: 196-209.

Acosta J., Canals M., López-Martínez J., Muñoz A., Herranz P., Urgeles R., Palomo C., Casamor J.L. 2002. The Balearic Promontory geomorphology (western Mediterranean): morphostructure and active processes. Geomorphology 49: 177-204.

Ardizzone GD. 2006. An introduction to Sensitive and Essential Fish Habitats identification and protection in the Mediterranean Sea. Working Document to the STECF/ SGMED-06-01 subgroup meeting on Sensitive and Essential Fish Habitats in the 
Mediterranean, Rome, March 2006.

Ballesteros E. 1988. Composición y estructura de los fondos de maërl de Tossa de Mar (Girona, España). Collect. Bot. (Barcelona) 17: 161-182

Ballesteros E. 1994. The deep-water Peyssonnelia beds from the Balearic Islands (Western Mediterranean). Mar. Ecol.-Pubbl. Staz. Zool. Napoli I 15: 233-253.

Begg G.A., Friedland K.D., Pearce J.B. 1999. Stock identification and its role in stock assessment and fisheries management: an overview. Fish. Res. 43: 1-8.

Begg G.A., Waldman J.R. 1999. An holistic approach to fish stock identification. Fish. Res. 43: 35-44.

Berntson E.A., Moran P. 2009. The utility and limitations of genetic data for stock identification and management of North Pacific rockfish (Sebastes spp.). Rev. Fish Biol. Fisher. 19: 233-247.

Bertrand J.A., Gil de Sola L., Papaconstantinou C., Relini G., Souplet A. 2000. Contribution on the distribution of elasmobranchs in the Mediterranean (from the MEDITS surveys). Biol. Mar. Mediterr. 7: 1-15.

Bertrand J.A., Gil de Sola L., Papaconstantinou C., Relini G., Souplet A. 2002. The general specifications of the MEDITS surveys. Sci. Mar. 66(Suppl. 2): 9-17.

BIOMAERL Team, 2003. Conservation and management of NE Atlantic and Mediterranean maerl beds. Aquat. Conserv. 13: S65-S76.

Bordehore C., Ramos-Esplá A.A., Riosmena-Rodríguez R. 2003 Comparative study of two maërl beds with different otter trawling history, southeast Iberian Peninsula. Aquat. Conserv. 13: 43-54.

Brown B.E., Darcy G.H., Overholtz W. 1987. Stocks assessment/ stock identification: an interactive process. In: Kumpf H.E., Vaught R.N., Grimes C.B. (eds.), Proceedings of the stock identification workshop. US Department of Commerce, Washington, D.C.

Cadrin S.X., Friedland K.D.,Waldman J.R. (eds.) 2005. Stock identification methods. Applications in fishery science. Elsevier, Amsterdam, $736 \mathrm{pp}$.

Canals M., Ballesteros E. 1997. Production of carbonate particles by phytobenthic communities on the Mallorca-Menorca shelf, northwestern Mediterranean Sea. Deep Sea Res. Pt II 44: 611-629.

Colloca F., Cardinale M., Belluscio A., Ardizzone G. 2003. Pattern of distribution and diversity of demersal assemblages in the central Mediterranean sea. Est. Coast. Shelf Sci. 56: 469-480.

Cope J.M., Punt A.E. 2009. Drawing the lines: resolving fishery management units with simple fisheries data. Can. J. Fish Aquat. Sci. 66: 1256-1273.

Danovaro R., Company J., Corinaldesi C., D’Onghia G., Galil B. Gambi C., Gooday A.J., Lampadariou N., Luna G.M., Morigi C. Olu K., Polymenakou P., Ramirez-Llodra E., Sabbatini A., Sarda F., Sibuet M., Tselepides A. 2010. Deep-sea biodiversity in the Mediterranean Sea: The known, the unknown, and the unknowable. PloS One 5(8): e11832.

Estrada M. 1996. Primary production in the northwestern Mediterranean. Sci. Mar. 60(2): 55-64.

EU 2006. Council Regulation (EC) No 1967/2006 of 21 December 2006 concerning management measures for the sustainable exploitation of fishery resources in the Mediterranean Sea. Of ficial Journal of the European Union, L 409/11-85.

Fernández A.M. 2010. Stock assessment of red mullet in GSA06. Sub-Committee on Stock Assessment, Istanbul, Turkey, 18-23 October 2010.

Fornós J.J, Ballesteros E., Massutí C., Rodríguez-Perea A. 1988 Red algae sediments in the Balearic Shelf. Rapp. Comm. int Mer Médit. 31: 2

Frank K.T., Brickman D. 2000. Allee effects and compensatory population dynamics within a stock complex. Can. J. Fish. Aquat. Sci. 57: 513-517.

García-Rodríguez M., Esteban A. 1999. On the biology and fishery of Aristeus antennatus (Risso, 1816), (Decapoda, Dendrobranchiata) in the Ibiza Channel (Balearic Islands, Spain). Sci. Mar. 63: 27-37.

García-Rodríguez M., Esteban A., Gil J.L.P. 2000. Considerations on the biology of Plesionika edwardsi (Brandt, 1851) (Decapoda, Caridea, Pandalidae) from experimental trap catches in the Spanish western Mediterranean Sea. Sci. Mar. 64: 369-379.

GFCM 2010a. Report of the 12th session of the scientific advisory committee (SAC). Budva, Montenegro, 25-29 January 2010. GFCM: XXXIV/2010/Inf.9, 212 pp.

GFCM 2010b. Report of the SCSA working group on stock assessment of demersal species. Istanbul, Turkey, 18-23 October 2010. GFCM: SAC13/2011/Inf.19, 91 pp.

Haddon M. 2001. Modelling and quantitative methods in fisheries. Chapman \& Hall/CRC, Florida, $424 \mathrm{pp}$.

Ihssen P.E., Booke H.E., Casselman J.M., McGlade J.M., Payne N.R., Utter F.M. 1981. Stock identification: materials and methods. Can. J. Fish. Aquat. Sci. 38: 1838-1855.

Lleonart J., Maynou F. 2003. Fish stock assessments in the Mediterranean: state of the art. Sci. Mar. 67: 37-49.

Lombarte A., Recasens L., González M., Gil de Sola L. 2000. Spatial segregation of two species of Mullidae (Mullus surmuletus and M. barbatus) in relation to habitat. Mar. Ecol. Progr. Ser. 206: 239-249.

Massutí E., Guijarro B. 2004. Recursos demersales en los fondos de arrastre de la plataforma y el talud de Mallorca y Menorca (Illes Balears). Resultados de las campañas BALAR0401 y BALAR0901. Inf. Tec. Inst. Esp. Oceanogr. 182, $132 \mathrm{pp.}$

Massutí E., Moranta J. 2003. Demersal assemblages and depth distribution of elasmobranchs from the continental shelf and slope off the Balearic Islands (western Mediterranean). ICES J. Mar. Sci. 60(4): 753-766.

Massutí E., Reñones O. 2005. Demersal resource assemblages in the trawl fishing grounds off the Balearic Islands (western Mediterranean). Sci. Mar. 69: 167-181.

Massutí E., García-Rodríguez M., Gil de Sola L., Guijarro B., Ordines F., García C., Ponce R. 2008. Informe campaña MEDITS_ES_2008. Instituto Español de Oceanografía, 219 pp.

Ordines F., Massutí E. 2009. Relationships between macro-epibenthic communities and fish on the shelf grounds of the western Mediterranean. Aquat. Conserv. 19: 370-383.

Ordines F., Massutí E., Guijarro B., Mas R. 2006. Diamond vs. square mesh codend in a multi-species trawl fishery of the western Mediterranean: effects on catch composition, yield, size selectivity and discards. Aquat. Living Resour. 19: 329-338.

Ordines F., Quetglas A., Massutí E., Moranta J. 2009. Habitat preferences and life history of the red scorpion fish, Scorpaena notata, in the Mediterranean. Est. Coast. Shelf Sci. 85(4): 537-546.

Palmer M., Quetglas A., Guijarro B., Moranta J., Ordines F., Massutí E. 2009. Performance of artificial neural networks and discriminant analysis in predicting fishing tactics from multispecific fisheries. Can. J. Fish. Aquat. Sci. 66: 224-237.

Pelletier D., Ferraris J. 2000. A multivariate approach for defining fishing tactics from commercial catch and effort data. Can. J. Fish. Aquat. Sci.57: 51-65.

Piet G.J., van Hal R., Greenstreet S.P.R. 2009. Modelling the direct impact of bottom trawling on the North Sea fish community to derive estimates of fishing mortality for non-target fish species. ICES J. Mar. Sci. 66(9): 1985-1998.

Reiss H., Hoarau G., Dickey-Collas M., Wolff W.J. 2009. Genetic population structure of marine fish: mismatch between biological and fisheries management units. Fish Fish. 10: 361-395.

Sampedro P., Saínza M., TrujilloV. 2005. A simple tool to calculate biological parameter's uncertainty. Working Document in Workshop on Sampling Design for Fisheries Data. ICES CM 2005/ACFM:11, Pasajes (Spain), 82 pp.

Sánchez P., Demestre M., Martín P. 2004. Characterisation of the discards generated by bottom trawling in the northwestern Mediterranean. Fish. Res. 67: 71-80.

Shaklee J.B., Currens K.P. 2003. Genetic stock identification and risk assessment. In: Hallerman E.M. (ed.), Population genetics: Principles and applications for fisheries scientists. American Fisheries Society, Bethesda, pp. 291-328.

Stevens J.D., Bonfil R., Dulvy N.K., Walker P.A. 2000. The effects of fishing on sharks, rays, and chimaeras (chondrichthyans), and the implications for marine ecosystems. ICES J. Mar. Sci. 57(3): 476-494.

Taylor B.L., Dizon A.E. 1999. First policy then science: why a management unit based solely on genetic criteria cannot work. Mol. Ecol. 8: S11-S16.

Thresher R.E. 1999. Elemental composition of otoliths as a stock delineator in fishes. Fish. Res. 43: 165-204.

Tserpes G., Fiorentino F., Levi D., Cau A., Murenu M., Zamboni A., Papaconstantinou C. 2002. Distribution of Mullus barbatus and M. surmuletus (Osteichthyes: Perciformes) in the Medi- 
terranean continental shelf: implications for management. Sci. Mar. 66: 39-54

Waldman J.R. 2005. Definition of stocks: an evolving concept. In: Cadrin S.X., Friedland K.D., Waldman J.R. (eds.), Stock Identification methods. Applications in fishery science. Elsevier, Academic Press, Amsterdam, pp. 7-16.

\section{ANNEX 1}

The fishing mortality (F) shown in Table 2 was taken from stock assessments performed during 2010 within the GFCM (www.gfcm.org) or STECF (https:// stecf.jrc.ec.europa.eu/). The software used in the assessments was the Lowestoft suite (Darby and Flatman 1994) in all cases except for the Norway lobster. The $\mathrm{F}$ used in these assessments was the arithmetic unweighted mean, which is referred to as Fbar. This arithmetic mean is calculated through the ages of the stock specified by the user and should include the ages fully exploited by the fishery. To make the values of $F$ comparable between areas, the data were standardized by calculating the $\mathrm{F}$ with the same ages and time series for each species: 1) Mullus barbatus and M. surmuleuts (Fbar0-2; time series: 2000-2009); 2) Merluccius merluccius (Fbar0-4; time series: 1995-2009); and 3) Aristeus antennatus (Fbar0-4; time series: 2002-2008).

Norway lobster assessments were carried out using VIT (Lleonart and Salat 1997). Data from GSA05 come from the assessment presented to the GFCM in 2010, but the only assessment available from GSA06
Scient. ed.: F. Maynou.

Received February 23, 2011. Accepted May 25, 2011.

Published online October 28, 2011.

was found in Sardà et al. (1998). VIT uses the Fmean, which is the average of all $\mathrm{F}$ values weighted by the time period considered (mortality on each size class varies over time). Sardà et al. (1998) ran VIT with males and females separately and under different natural mortality conditions ( $M=0.1,0.2$ and 0.3 ). Given that the assessment from GSA05 was made using both sexes combined and an $\mathrm{M}$ close to 0.3, the values of Sardà et al. (1998) used for GSA06 were the mean of males and females under an $\mathrm{M}=0.3$.

\section{References}

Darby C.D, Flatman S. 1994. Virtual Population Análisis: version 3.1 (Windows/DOS) user guide. Info. Tech. Ser., MAFF Direct. Fish. Res., Lowestoft, $\mathrm{N}^{\mathrm{o}} 1,85 \mathrm{pp}$.

Lleonart J., Salat J. 1997. VIT: Software for fishery analysis. User's manual. FAO Computerized Information Series (Fisheries), $\mathrm{N}^{\mathrm{o}}$ 11, Rome, FAO, 105 pp.

Sardà F., Lleonart J., Cartes J.E. 1998. An analysis of the population dynamics of Nephrops norvegicus (L.) in the Mediterranean Sea. Sci. Mar. 62(Supl. 1): 135-143. 